\title{
The Yin and Yang of Dictionary Making: Slovenian Lexicographers Reflect
}

\author{
Alenka Vrbinc, School of Economics and Business, \\ University of Ljubljana, Slovenia (alenka.vrbinc@ef.uni-lj.si), \\ Donna M.T.Cr. Farina, Department of Multicultural Education, \\ New Jersey City University, New Jersey, USA (dfarina@njcu.edu) \\ and \\ Marjeta Vrbinc, Faculty of Arts, University of Ljubljana, Slovenia \\ (marjeta.vrbinc@ff.uni-lj.si)
}

\begin{abstract}
This contribution presents the second and final report on a study that set out to gain a greater understanding of what general modern Slovenian lexicography is. The full study focused on the philosophy, accomplishments, daily practice, and dictionary projects of seven prominent members of the Slovenian lexicographic community, all of whom were interviewed at length. An open-ended interview script allowed study participants to both reflect on their practice and portray their vision of what lexicography or terminography is. Part 1 (Vrbinc, Farina and Vrbinc 2018a; 2018b) reported on whether the lexicographers saw their work as drudgery and what they saw as the nature of their role in the society. Here, in Part 2, the emphasis is on the day-to-day concerns of the participating Slovenian lexicographers. They discuss both the technological and the human resources that drive their work. This second report also includes a brief survey of the historical development of Slovenian lexicography as the necessary backdrop for the interpretation of the modern situation.
\end{abstract}

Keywords: INTERVIEW, LEXICOGRAPHER, LEXICOGRAPHIC PHILOSOPHY, LEXICOGRAPHIC PRINCIPLES, LEXICOGRAPHIC THEORY, LEXICOGRAPHIC PRACTICE, SLOVENIAN LEXICOGRAPHY, HUMAN RESOURCES, TECHNOLOGICAL RESOURCES, CROWDSOURCING

Opsomming: Die negatiewe en positiewe van woordeboekmaak: Beskouings van Sloweense leksikograwe. Hierdie bydrae stel die tweede en finale verslag van ' $n$ studie wat daarop gemik is om 'n beter begrip van die algemene moderne Sloweense leksikografie te verkry, bekend. Die volledige studie het gefokus op die filosofie, prestasies, daaglikse praktyk, en woordeboekprojekte van sewe prominente lede van die Sloweense gemeenskap met wie almal indringende onderhoude gevoer is. 'n Oop onderhoud het deelnemers aan die studie toegelaat om na te dink oor wat hulle doen en om ook weer te gee wat hul visie van die leksikografie of terminografie is. Deel 1 (Vrbinc, Farina en Vrbinc 2018a; 2018b) het verslag gedoen oor of leksikograwe hul werk as sleurwerk ervaar en wat hulle as die aard van hul rol in die gemeenskap beskou. Hier, in deel 2, is die klem op die daaglikse probleme van die deelnemende Sloweense leksikograwe. Hulle 
bespreek beide die tegnologiese en menslike hulpbronne wat as dryfkrag vir hul werk dien. As noodsaaklike agtergrond vir die interpretasie van die moderne situasie bevat die tweede verslag ook 'n kort oorsig van die historiese ontwikkeling van die Sloweense leksikografie.

Sleutelwoorde: ONDERHOUD, LEKSIKOGRAAF, LEKSIKOGRAFIESE FILOSOFIE, LEKSIKOGRAFIESE BEGINSELS, LEKSIKOGRAFIESE TEORIE, LEKSIKOGRAFIESE PRAKTYK, SLOWEENSE LEKSIKOGRAFIE, MENSLIKE HULPBRONNE, TEGNOLOGIESE HULPBRONNE, SKAREBENUTTING

\section{Introduction}

To a certain degree, dictionaries are created and delivered in similar ways worldwide. Bilateral and multilateral lexicographic work takes place between organizations (such as AFRILEX, ASIALEX, DSNA, and EURALEX) and between academies of science (such as the Austrian or Slovenian academies). While some lexicographers network through conference attendance and keep up with the scholarly literature, others are not able to follow every new development in the field. The present discussion is the second report based on an interview study of lexicographers. Its intended audience is any lexicographer, hardpressed for time, who might wish to know more about what other lexicographers do and who might benefit from such information in daily practice. Before the full interview study was conducted, the authors were (and are still) not aware of the existence of any studies of practicing lexicographers. In the previous (Vrbinc, Farina and Vrbinc 2018a; 2018b) and in the present report, Slovenian lexicography is accessed via the perspectives of seven prominent lexicographers. Other researchers are encouraged to replicate this study in their own countries, to advance lexicographic theory as well as practice globally.

During February-March 2017, seven Slovenian lexicographers were interviewed over sixteen hours. Four overarching questions drove the full research study and the creation of an open-ended interview script:

A. What is the philosophical and intellectual framework governing the work of Slovenian lexicographers? What ideas do they all share - across different institutions and projects - as they engage in making dictionaries?

B. What are the main areas of concern and common significant problems that inform the work of Slovenian lexicographers?

C. What do the lexicographers consider both the main strengths and the weaknesses of their current efforts in dictionary creation? What would they most like to change about their practice?

D. What are the differences among our interviewees in their conception of what lexicography is all about? 
The first report on the study's findings investigated the philosophy of the interviewees and focused on Research Question A above, with some elements of Research Question D. It explored views on prescription versus description, drudgery, and the role of the lexicographer as "harmless" or not (Vrbinc, Farina and Vrbinc 2018a; 2018b). This second and final report has an entirely different focus. It seeks answers to Research Questions B and C by investigating the seven lexicographers' work challenges and constraints, the major strengths of their current work situations, and the changes that they would like to see in future dictionary work. Note that only seven subjects were interviewed. From the outset, the full study was never intended to present an exhaustive picture of Slovenian lexicography; the study's findings might be different if more interviews were held or if different people were interviewed. Nevertheless, since the lexicographers interviewed all work on different projects and in different institutional settings (or independently), the present report as well as Report 1 does claim to provide important information on some of the pressing issues in lexicography today.

The present report is relevant to dictionary makers around the globe interested in improving their local lexicographic practice. By listening to the Slovenian lexicographers, we might all gain insight into what future practices could be most beneficial for our field. This report is also relevant to Slovenian theoreticians and practitioners of lexicography who wish to understand better the place of their work in the social context prevailing today - and the place of their work within the full history of Slovenian lexicography.

\section{A short history of Slovenian lexicography}

As indicated above, the main objective of this report is to examine the work situation of Slovenian lexicographers today (Research Questions B and C above). In the case of Slovenia, to interpret today it is necessary to inspect yesterday, at least briefly. Speakers of the Slovenian language have known rule under the Habsburg Monarchy (1282/1335-1918), under the Austro-Hungarian Empire (1867-1918), and as part of the former Yugoslavia (1918-1991); Slovenia has been an independent country only since 1991 . While by 1775 all children were required to attend school on the territory of modern Slovenia, the full use of the Slovenian language as the main medium of instruction at all educational levels is a relatively new development. In the second half of the nineteenth century, German was still the language of instruction for high school and university-level education. This state of affairs impacted the development of the Slovenian language as well as Slovenian lexicography.

Early literacy in Slovenia was connected with religion and dates to the late sixteenth century. In 1584, the first Slovenian word list was included in Dalmatin's Protestant Bible (Biblia, tu ie, vse Svetu pismu ...), the first translation of the Bible into Slovenian. The first print dictionary to include Slovenian words is Megiser's Dictionarium quatuor linguarum ... (1592); it has headwords in Ger- 
man, followed by Latin, Slovenian, and Italian equivalents. A later dictionary by Megiser, the Thesaurus polyglottus (1603), included many more languages, among these: French, German, Greek, Hebrew, Hungarian, Latin, Polish, Slovenian, and Spanish.

These early Slovenian word lists and dictionaries with very simple equivalents gradually transitioned into a full-fledged bilingual lexicography, where more than simple equivalence was provided between a single pair of languages rather than a series of them. One hundred years later, by the end of the seventeenth century, high-quality bilingual dictionaries with Slovenian appeared, such as Ožbalt Gutsman's Deutsch-windisches Wörterbuch (in German, windisch is an old word for Slovenian) of 1789. Two well-respected dictionaries from the late nineteenth century with German and Slovenian are Maks Pleteršnik's Slovenian-German Dictionary [Slovensko-nemški slovar] (two vols., 1894-1895) and Matej Cigale's German-Slovenian Dictionary [Deutsch-slowenisches Wörterbuch] (1860). The first bilingual Slovenian dictionaries with English were intended for Slovenian immigrants to the United States: Košutnik's A Pocket Slovenian-English and English-Slovenian Dictionary: Intended for Immigrants to America [Ročni slovensko-angleški in angleško-slovenski slovar: zlasti namenjen za izseljence v Ameriko] (Ljubljana) of 1904 and Kubelka's Slovenian-English Pocket Dictionary, [Slovensko-angleški žepni rečnik], published in New York the same year.

No monolingual Slovenian dictionary existed until late in the twentieth century. Merše (2009) explains that before World War II, there was no special institute for the study of Slovenian. The Slovenian Academy of Sciences and Arts itself was established only in 1938, just before World War II. Within the Academy, the Institute of the Slovenian Language was established in 1945; today this is called the Fran Ramovš Institute after its first director. ${ }^{1}$ Only in the 1950s did work begin on what would become the first monolingual Slovenian dictionary. In 1970, the first volume of The Dictionary of Standard Slovenian [Slovar slovenskega knjižnega jezika] (letters A to H) was published; all five volumes had appeared by 1991. In 1997, the full dictionary was reprinted in a single volume. The two-volume second edition appeared in print in 2014; it is now available online. Following an intense period of discussion and planning, work began in 2016 on the e-Dictionary of Standard Slovenian (eDSS) [eSSKJ]. While this new dictionary is informally called the "third" edition, it is conceived as an entirely new work rather than a revision of the earlier editions. It is being delivered to the public in once-per-year increments on FRAN, ${ }^{2}$ the online dictionary portal of the Academy of Sciences (https://fran.si/). Approximately 500 entries are posted each year, with today's total at 1641. Current plans envisage that a print edition will be made available when the dictionary is complete.

Apart from monolingual lexicographic work taking place within the Academy of Sciences, from the mid to the late twentieth century there was an active independent bilingual lexicography in Slovenia; many dictionaries appeared from a variety of publishing houses. Apart from the existence of several small English and Slovenian dictionaries for immigrants to the US, starting in 
the late nineteenth century and continuing up to the end of World War II (for example, Košutnik 1904 and Kubelka 1904), the pairing of Slovenian with English is a relatively late phenomenon. Škerlj's English-Slovenian Dictionary [Angleškoslovenski slovar], did not appear until 1944; it arose out of communication needs anticipated by the intellectual community during World War II (Rener 2007). The first monodirectional Slovenian-English dictionary, Kotnik's Slovensko-angleški slovar, appeared in 1945. More comprehensive coverage came much later, with the English-Slovenian dictionary [Angleško-slovenski slovar] of Grad et al. (1973). A larger work was published in 1978 (Grad et al., Comprehensive English-Slovenian Dictionary [Veliki angleško-slovenski slovar]). Krek's Oxford-DZS Comprehensive English-Slovenian Dictionary [Veliki angleško-slovenski slovar Oxford] appeared in the new century, 2005-2006, as did the Angleško-slovenski slovar of Vrbinc and Vrbinc (2009).

Due to close cultural ties, a pairing with the German language has been consistent throughout the Slovenian lexicographic tradition. In modern times, the Debenjak family's (Doris, Primož and Božidar Debenjak) Comprehensive German-Slovenian Dictionary [Veliki nemško-slovenski slovar] first appeared in 1992 and has remained in print, with the last publication in 1999. Their Comprehensive Slovenian-German Dictionary [Veliki slovensko-nemški slovar] of 1995 is likewise used to this day. After Slovenia gained independence from the former Yugoslavia in 1991, bilingual lexicography became more varied and comprehensive. There now exist recent dictionaries of Slovenian with Slavic languages (Czech, Polish, Russian, and Serbo-Croatian) as well as with Dutch, French, Italian, and Spanish. Unfortunately, just as the public's need for bilingual lexicographic tools has increased, Slovenian publishing houses have ceased to publish such print dictionaries.

Slovenian bilingual lexicographic work takes place outside of the Slovenian Academy of Sciences, which focuses on monolingual lexicography. Today in the Academy there are dictionaries or ongoing projects on orthography, synonymy, phraseology, and terminology (to name a few). However, monolingual work is not limited to Academy projects. In 2004, Trojina, Institute for Applied Slovene Studies, was founded in Ljubljana to promote linguistic research and the linguistic competence of Slovenian speakers. Trojina collaborates on projects with other institutions or academic units engaging in lexicographic work, at the University of Ljubljana and beyond. ${ }^{3}$

\section{The Slovenian study participants}

Within the short time frame allotted for this study, we sought to represent as many locations as possible where dictionaries are being made in Slovenia, and to cover a variety of types of modern dictionary work. Only specialists who work on synchronic topics and concentrate on the standard language (as well as terminology) were interviewed. The Fran Ramovš Institute of the Slovenian Language in the Academy of Sciences and Arts is a center of dictionary work in 
Slovenia. In the Lexicological Section, three of our interviewees concentrate on different aspects of lexicography: Nataša Jakop, Nina Ledinek, and Jerica Snoj. In another area of the Ramovš Institute, Mojca Žagar Karer has worked on numerous terminological dictionaries and directs the Terminological Section.

Apart from the Fran Ramovš Institute, there are ongoing lexicographic projects in a variety of units at the University of Ljubljana. There are also projects led by Trojina, Institute for Applied Slovene Studies, usually in cooperation with other units. We interviewed Apolonija Gantar and Iztok Kosem, researchers in the Faculty of Arts at the University of Ljubljana.

Lexicography in Slovenia does not only take place via institutionally-supported projects. Anita Srebnik is an independent lexicographer who authored the Slovenian-Dutch European Dictionary [Slovensko-nizozemski evropski slovar] (2006) and the Dutch-Slovenian Dictionary [Nizozemsko slovenski slovar = Nederlands Sloveens woordenboek] (2007), intended for Slovenian learners of Dutch. She is also an instructor of Dutch in the Faculty of Arts at the University of Ljubljana.

Due to their positions and influence, the reflections of these seven study participants are not anonymous; here, they are cited by name in order to advance lexicographic practice. The seven interviewees were given the option to speak "off the record," to make comments that would not be directly attributed to them. We received very few such comments; the participants were frank and forthcoming. For more detailed information on our subjects and how they were selected, see Vrbinc, Farina and Vrbinc (2018a), sections 7 and 8.

\section{The prevailing themes}

Given that our full study sought to encourage future interview-based research on lexicographers worldwide, the interview script was published in its entirety (see Report 1, Vrbinc, Farina and Vrbinc 2018a; 2018b). While all of the interview questions informed Report 1 directly or indirectly, two of them, Script Questions $3 a$ and $3 b$, were the main focus there. Three of the thirteen questions from the scripted interviews with the lexicographers serve as the main source of information here in Report 2; the answers to other questions were also consulted. Script Questions 10, 11, and 12 dealt with the challenges and obstacles the Slovenian lexicographers are confronted with as they try to deliver their products to users:

10. It goes without saying that lexicographic work takes place in the real world and is subject to the usual constraints and challenges of any practical work. In particular, there are always budgetary constraints, but not only budgetary. We would like to know: How is your work challenged by a variety of circumstances; what are the challenges and constraints?

11. Can you name the major strengths of your work situation? What is a best practice for you and your colleagues (e.g., access to different information/ sources, user-friendly dictionary-making software, cooperation with IT 
specialists and/or corpus linguists and/or experts from other fields, etc.)? What affects most positively the compilation of your dictionaries?

12. If you could change one thing about the circumstances of your lexicographic work, what would it be? If you could change one feature of the lexicographic philosophy/theory that underpins your work, what would it be?

We identified holistically some themes that came up from the responses to these three questions; they are addressed below. Most often, the same or similar themes arose in interviews with more than one person. We also included some ideas that can be considered relevant to our field even if they may not have come up repeatedly. Gouws (2012) provided a helpful framing for our discussion below. He asked: Who is a lexicographer? What does such a person do and what skill set should they have? Gouws identified four groups of people: (1) lexicographic practitioners without theoretical experience; (2) theoreticians without practical experience; (3) those who are primarily practitioners but have some theoretical background; and finally (4) theoreticians who have some practical experience (2012). Many aspects of Gouws' framing had parallels in the remarks of our study participants as they considered both the human and technological resources that contribute to successful dictionary projects.

\subsection{Budget considerations}

Our Question 10 above, while it mentions budget, was intended to steer the subjects toward addressing non-budgetary, non-financial constraints. Nevertheless, every informant felt compelled to speak about the role that financial constraints play in lexicographic work. It was impossible for them not to speak of this, when budget affects almost every aspect of lexicography. Because this is already a familiar problem, their comments on budget are interwoven within the topics raised below.

\subsection{Human resources}

Given the technological nature of much modern dictionary work, it is common for the question of lexicographic resources to be considered as primarily one of hardware and software. However, our participants had many comments about the people in lexicography, the human resource.

\subsubsection{Experts and expertise}

The theme of experts and expertise arose often. Nataša Jakop of the Ramovš Institute brought up what she saw as a lack of the necessary expertise for lexi- 
cography in Slovenia, a very small country (with a population of just above two million persons). She considered that a lexicographer needs to bring to the table an area of expertise, but not necessarily lexicography itself; this would correspond partially with Gouws' (2012) categories (3) or (4), practitioners with some theoretical background or theoreticians with some practical experience. According to Dr. Jakop, in order to be part of a dictionary-making team, a person needs training in phonology as well as other aspects of linguistics, corpus linguistics, information technology, and other areas. The ideal lexicographic team would have many different types of specialists on staff. Dr. Jakop noted that in a small country it is difficult to have all the necessary specialists on board for a single project; what is more, the budget for a large team is rarely available. This means that while technologically it would be possible to make a dictionary in five to ten years, without the budget for a sufficient number of experts, this is not likely to happen.

The terminographer among our study participants, Mojca Žagar Karer of the Ramovš Institute is satisfied with her experiences with specialists: She considers that working with the excellent and dedicated experts at the Ramovš Institute is a major advantage of her work situation. On the other hand, she encounters lack of motivation among the terminological field experts outside of the Ramovš Institute, who must constantly be encouraged to contribute. We might add: It is quite understandable that persons (such as the experts from other fields) who are not trained in lexicography would find the writing of terminological dictionary entries to be an onerous process.

Iztok Kosem, affiliated with Trojina, the Institute for Applied Slovene Studies, and the Faculty of Arts at the University of Ljubljana, alluded to the expertise of Slovenian lexicographers, who as a group are internationally wellconnected and established. People from other countries want information from them, which can be considered a compliment. Recently, people from Portugal and Estonia traveled to Slovenia to see the methodology being used. They ended up improving upon the Slovenian technology for their target languages as well as upon the whole procedure.

As a form of expertise enhancement for themselves, Dr. Žagar Karer and Dr. Jakop would like more opportunities to attend conferences and workshops. Dr. Kosem pointed out that twenty years ago, lexicographers had to travel to get information, to talk to people. Now, more information can be obtained more easily for collaboration.

\subsubsection{Cooperation and staffing}

Most of the interviewees identified cooperation as a major strength in their work situations. Nataša Jakop noted that lexicographers in the Ramovš Institute can communicate with etymologists, orthographists, dialectologists, terminologists, and a large variety of other specialists. They can consult specialists in other fields (e.g., geography, anthropology), since the Ramovš Institute is 
only one of eighteen institutes within the Academy of Sciences. Nina Ledinek in the Ramovš Institute noted how helpful it is to have so many specialists in different fields of linguistics, as well as experts in other areas of science employed at the Academy - there is always someone who can help with a problem. These experts have different backgrounds and specializations; they are young, enthusiastic, prepared, and eager to collaborate on problem-solving. Similarly, Mojca Žagar Karer emphasized her cooperative working environment, stating, "I am lucky with my colleagues."

Apolonija Gantar of the University of Ljubljana mentioned the cooperation between linguists and IT specialists (students and professors at the Faculty of Computer and Information Science who are interested in linguistic work). Jerica Snoj of the Ramovš Institute referred to a linguist/IT collaboration as the best experience of her lexicographic career. When her team began work on the Dictionary of Slovenian Synonyms in 2001, there was no appropriate program for writing and editing entries. The younger colleagues designed a program for this project, in line with the plan of the dictionary, that was completed in 2013. Dr. Snoj emphasized that it was the lexicographers/linguists who provided the programmers with very detailed instructions. She further noted that it is a very positive thing when lexicographers are supported by the appropriate technology. Iztok Kosem cited the value of international cooperation. There are numerous mutual projects and sometimes Slovenian lexicographers collaborate with foreign partners even when they do not receive funding. Dr. Kosem mentioned that he and his co-workers always strive to include people with knowledge of how to make information user-friendly and to have ongoing interactions with them.

Given the positive collaborations experienced by the study participants, it is not surprising that they expressed a desire for more collaboration - in the form of larger lexicographic staffs or teams. Nataša Jakop would like to have a bigger team working on phraseology (at the time of this study, three colleagues were working in this area); she considered that more specialists in lexicography should be working on every project. Dr. Jakop would also like to have more support staff (e.g., students) for some of the preliminary monotonous work, which is time-consuming and expensive. Similarly, Apolonija Gantar noted that there are levels of dictionary work that can be done by people with less expertise (fewer years of experience, trainees, students, crowd-sourcing). Nina Ledinek considered that hiring more people would allow for faster production as well as more accurate dictionary products. Dr. Ledinek maintained that while disagreements among specialists will never go away, they might be diminished if an improved financial situation reduced competition; competition for projects can be counterproductive. Mojca Žagar Karer, the only terminographer among our interviewees, agreed with Drs. Jakop and Ledinek that more people should be working on every project. In the case of terminological dictionaries, this means more (non-lexicographic) experts in each subject/field are needed, as terminographers are generally overburdened. 


\subsubsection{Crowd-sourcing}

Crowd-sourcing has been seen by some in our field, including some of our study participants, as a possible solution to the problem of understaffing in lexicography. In their examination of crowd-sourcing in German and English versions of Wiktionary, Wolfer and Müller-Spitzer (2016) express skepticism that any solely crowd-sourced dictionary could reach the levels of quality seen in dictionaries created by professionals. Likewise, Sajous, Josselin-Leray, and Hathout (2018) see crowd-sourcing of neologisms (as examined in four dictionaries) as something complementary to but not replacing professional lexicographic work. Among our study participants, Apolonija Gantar mentioned crowd-sourcing in conjunction with discussion of budgetary problems. She considered that the distribution of public monies in lexicography is problematic and that projects could be carried out more cheaply if crowd-sourcing were used. Her remarks advocate for crowd-sourcing to both supplement and accelerate lexicographic work. Wolfer and Müller-Spitzer (2016) mention another positive of crowd-sourcing: "... it is a pleasure to see that there is a languageinterested community that works on dictionaries voluntarily. Is this not also a sign for the relevance of dictionaries?" (368). While not mentioning crowdsourcing directly, Mojca Žagar Karer noted that she gets good, satisfying feedback from the users of the terminological dictionaries who use the Ramovš Institute's consulting service.

Iztok Kosem mentioned crowd-sourcing as a convenient supplement to the work of lexicographic specialists. If users participate in contributing to a dictionary, it allows the team of experts to focus on more complex tasks such as defining or addressing phraseology and compounds. Dr. Kosem and his colleagues are trying to devise crowd-sourcing "tests" for people. For example, if volunteers are asked to attribute an illustrative example to a particular sense of a word, this gives the lexicographic team feedback as to whether their own division of senses is appropriate or whether an example should be linked to a given sense. Dr. Kosem noted that the dictionary user of today is more demanding: "Users are used to getting information instantly, participating, and having an opinion," and crowd-sourcing can favorably affect this dynamic by engaging users more. Dr. Kosem welcomes the new challenges caused by this type of user, "You cannot be proud of your dictionary if the user does not use it." He envisages each student coming to the dictionary with their own profile that the dictionary would adapt to. For example, a student of biology would see more illustrative examples in that field.

\subsection{Technological resources}

Our study participants expressed many opinions on the technological resources available to them for dictionary work. While they are glad to have modern tools available, they are not always fully satisfied with them and perceive that 
their current tools are often not adequate to the tasks at hand. Anita Srebnik, an independent lexicographer, emphasized that software, different corpora and online dictionaries are more accessible now than they were in 2003, when she started her work on bilingual Slovenian-Dutch dictionaries. She considers support from language technology specialists to be absolutely essential in any lexicographic project.

Nina Ledinek of the Ramovš Institute would like better IT support. In addition, having access to different corpora would help her with her work: The corpus materials she is using now are ten or fifteen years old and do not contain enough Slovenian language material from the 1970s, 80s and 90s. Likewise, Iztok Kosem of Trojina and of the University of Ljubljana noted that the current Slovenian reference corpus (Gigafida) is 6 years out of date. Dr. Ledinek also mentioned that better dictionary software is needed; Mojca Žagar Karer made similar remarks. Jerica Snoj of the Ramovš Institute pointed out that not every corpus is useful for work on a dictionary; most of them were not initially designed for lexicography but for general linguistic investigations. For example, she would like to be able to look up full collocations or grammar points. Nataša Jakop of the Ramovš Institute would like to have a more automated way of selecting data and illustrative material. Finally, Dr. Snoj would like to change the belief that language technology alone is enough to make a modern dictionary without other linguistic knowledge; in her opinion, this is a dangerous idea that is growing in popularity.

The participants' discussion of technological resources overlapped with their discussion of human cooperation. Apolonija Gantar, researcher at the University of Ljubljana, believes that access to different information sources, user-friendly dictionary-making software, and cooperation with IT specialists and/or corpus linguists and/or experts from other fields all affect dictionary work positively. According to Dr. Gantar, people working at the Center for Language Resources and Technologies have all of this. Since every dictionary has a different underlying lexicographic concept, it goes without saying that the lexicographers must adjust to different projects; they have to get familiar with corpora and the information they can obtain in corpora.

Most interviewees noted how essential cooperation is between linguists and IT specialists, and some perceive a need for better cooperation. Iztok Kosem, a researcher at Trojina and the University of Ljubljana considers that the best lexicographic team has some people who know technology better and some "doubters" who challenge your ideas - whom you have to convince by providing explanations. In general, our participants' ideas are in line with Tarp (2012):

The final conclusion is that lexicography will not cease to be an independent discipline with its own specific subject field as well as its own theory and practice but that it will tend to relate more and more to and interact with similar disciplines within the broad area of information science. ... [L] exicographical theory will place itself in an even better position to assist and guide the present transition from printed to electronic dictionaries. (329) 


\subsection{Theory and practice}

Reflections on lexicographic theory found in the current literature have commonalities with the views of our distinguished interviewees. Anita Srebnik, an independent bilingual lexicographer, believes that current practices are ahead of theory; this is similar to Piotrowski (2013), who is skeptical of the validity of past theoretical models for our time, when rapid changes are taking place in both cultural and technological environments. Dr. Srebnik mentioned that new tools require the articulation of new theory as to how to use them; this recalls Gouws' (2018) exploration of guidelines for the adaptation of "different types of data distribution structures in online dictionaries" (178) as part of the transition from print to online. In line with Wiegand's famous 1984 pronouncement that lexicography is not a science and will not become one, ${ }^{4}$ Srebnik considers theory and practice as two completely separate endeavors.

Apolonija Gantar, researcher at the University of Ljubljana, did not mention directly theory versus practice, but her remarks seem to speak to the separate "theoretical" statements that are imbued in each dictionary implicitly. Dr. Gantar believes that having more than one general monolingual dictionary of standard Slovenian would be good for Slovenia, because that would help people arrive at their own opinions about language; such multiple dictionaries as cultural artifacts would reflect a range of different user needs. This echoes FuertesOlivera and Tarp (2014), who note that dictionaries have covered "a wide range of different needs detected in society and ... almost all spheres of human activity and knowledge" (39). Dr. Gantar maintained that dictionaries, as reference works intended for general users (who want to solve different linguistic problems) rather than for linguists, should allow room for users to doubt the very information they provide. Dictionary users should be able to rely on themselves and their own judgements. Users, in Dr. Gantar's opinion, should be more self-confident in their own linguistic knowledge. Another of our interviewees agreed with Dr. Gantar's desire for more than one general Slovenian dictionary, and emphasized that clashes in theory, rather than just competition for project money, drive the current Slovenian paradigm of a single large monolingual dictionary. This remark fits with the notion that a dictionary is itself a kind of theory; it possibly fits as well with Piotrowski's (2013) idea that there are multiple lexicographic theories.

Iztok Kosem, a researcher at several institutions including the University of Ljubljana, mentioned the necessity of engaging in multiple dictionary projects simultaneously, since a single project will only provide partial employment financially. Dr. Kosem noted that when a researcher writes a grant proposal, s/he must wait for the results of funding; some worthy projects are not funded at all (e.g., the comparative European project on dictionary use). It is not possible to focus, Dr. Kosem said, on a single project over a sequence of months or years, and when a researcher has too many projects it is difficult to master any one. Dr. Kosem would like to have not too many but more than a 
single lexicographic project active at once. Luckily, he was able to connect work on a Slovenian-Hungarian dictionary and on a collocations dictionary in terms of reusing some skills and methods. While Dr. Kosem's remarks were intended to address the financial realities as well as the uncertainties of lexicographic work in the real world, they also have theoretical implications. A project that begins through a well-articulated grant proposal risks losing its theoretical focus as work is dragged out due to the vagaries of funding; moreover, very good projects that would advance lexicographic theory risk not coming to fruition.

Anita Srebnik, the only independent lexicographer in our group, to some extent echoed the concerns of Dr. Kosem, but with a different emphasis. In her case, she has non-lexicographic full-time employment (as an instructor of Dutch at the University of Ljubljana) that prevents her from being fully dedicated to lexicographic work. For this reason, it took her seven years to compile her bilingual Dutch-Slovenian dictionary. She found the organization of dictionary work to be very time-consuming and would have appreciated being part of a team that could have provided more support for her efforts. She came into lexicography without prior formal training and this also presented a challenge; for Gouws (2012), she would be considered in category (1), a practitioner who lacked theoretical experience. While such practitioners can succeed in creating outstanding products, Dr. Srebnik underlined that such conditions of lexicographic practice are far from ideal for lexicographic theory.

Nina Ledinek of the Fran Ramovš Institute enumerated several problems connected with everyday lexicographic work. Among other things, she considered that more material relevant to lexicography is needed on the standard language and language stratification. Lexicographers need to determine what is the standard language, what is dialectal, colloquial, etc. for dictionary work. While theory was not mentioned directly by this participant, it is clear that an important, if not the most important, element of lexicographic theory is the point of view of the lexicographer on the standard language (cf. Farina 2020).

Another problem Dr. Ledinek raised is that Slovenian Orthography [Slovenski pravopis], an important reference tool for the country, ${ }^{5}$ is out of date since it was published in 2001 and users' habits have changed since then. This brings to mind Dr. Jakop's comment (above) about the desirability of completing dictionaries in five to ten years. When longer periods of time pass, a research tool may no longer be as effective: Either a work's underlying theory may cease to be suitable to modern reality or the theory underlying the work may lose focus due to the passage of time.

While some of the remarks above appear to indicate a recognition that there is no one lexicographic theory, nevertheless some interviewees do perceive that there is a prevailing general theory that guides their work. Mojca Žagar Karer of the Ramovš Institute maintains that there is no need to change lexicographic theory, but she would like to have more time to reflect on the theory and philosophy of her field, terminography. Dr. Gantar agrees with Dr. Žagar 
Karer that the current state of lexicographic theory is acceptable, but adds that she is free to develop theory or change it if she wishes, through the publication of articles and the presentation of papers at conferences.

\section{Conclusions and recommendations}

This second and final report on an interview study of seven prominent Slovenian lexicographers brings home the potential of the interview process to contribute to our understanding of modern lexicography. It would be impossible for our field to advance without the theoretical and practical contributions of the leading academic journals. In addition to these, the perspectives of the leading, working lexicographers "on the ground" provide an entirely different and valuable knowledge source. Just as dictionaries are cultural artifacts, embedded in the time and place of their creation, so lexicographers are cultural emissaries who both represent the users of the language and - as some study participants point out - collaborate or engage with users in the creation of or understanding of dictionary information. While these emissaries may be seen as "invisible" or "harmless" (see Vrbinc, Farina and Vrbinc 2018a) and may heretofore have been mostly ignored as subjects for scientific study, this is an oversight when much may be gained from listening to them. It is hoped that similar interviews will be conducted in other countries, to build a deeper comparative understanding of lexicographic ideas and work practices. It is worth considering whether the lexicographic product of a single nation can be evaluated fully without this type of grounded perspective from real lexicographers.

As a country, Slovenia is blessed with a powerful cadre of lexicographic experts, due in no small part to its successful programs for training future specialists (see Vrbinc, Farina and Vrbinc 2018a). For this reason (as one study participant points out), Slovenian lexicography has attracted international attention and has benefitted from international collaborations. This is a significant asset that could position Slovenia as a world leader in all things lexicographic. It is no small achievement for a country of only about two million people.

The Slovenian lexicographers interviewed expressed satisfaction with their work as well as with most aspects of their work situations. The study authors are left nevertheless with the impression of a lexicographic infrastructure that is inequitable. The interviews brought out that some Slovenian lexicographic work is independent and entirely uncompensated; some work is dependent on soft monies (i.e. grants) that might not be renewed, thus rendering some projects precarious; finally, some work is stable and supported institutionally on a permanent, ongoing basis. It is obvious that this situation may adversely affect the finances of the lexicographers themselves. Without the interviews, it would not be as clear how this state of affairs impacts the quality or the quantity of dictionary products, or how it affects theoretical innovation and long-term lexicographic development. Our participants are aware of the impact - though they are too busy being lexicographers to dwell on it. They 
are aware of missed opportunities for dictionaries based on alternate theoretical premises, something that could potentially provide users with more choices and provide lexicography with more possibilities to develop as a discipline. Participants mentioned the need for fewer disagreements as well as less forced competition among specialists, the need to allow similar projects with different theoretical goals to coexist, and the need for better use of existing resources. Most likely, similar situations prevail in other countries. This is all the more reason to have interviews with specialists elsewhere, to provide us with that comparative picture.

\section{Acknowledgements}

This study could not have taken place without the cooperation, patience, and candor of our seven Slovenian lexicographer-interviewees. Many thanks to: Apolonija Gantar, Nataša Jakop, Iztok Kosem, Nina Ledinek, Jerica Snoj, Anita Srebnik, and Mojca Žagar Karer. As this second report on our interview study indicates, these high-level specialists allowed us to meet them where they live professionally, to bring a new and unique insight to lexicographers everywhere. Additionally, we thank Marko Snoj, the director of the Fran Ramovš Institute of the Slovenian Academy of Sciences, for welcoming us there.

The authors acknowledge the project, Lexicographic exchange as a way of building bridges between Slovenian and American lexicographic philosophy, governing principles, goals, and work tools, No. BI-US/16-17-053, which was financially supported by the Slovenian Research Agency. They also acknowledge the approval (20 February 2017) of the New Jersey City University (NJCU) Institutional Review Board for the Protection of Human Participants in Research. Donna Farina thanks NJCU for travel support to Ljubljana, Slovenia, as well as released time support from its Separately Budgeted Research program. The authors thank NJCU, in particular Tamara Cunningham, Assistant Vice President for Global Initiatives, for providing housing and hospitality to Alenka Vrbinc and Marjeta Vrbinc during their research visit to the United States.

\section{Endnotes}

1. Fran Ramovš (1890-1952) was a Slovenian linguist and a co-founder and member of the Slovenian Academy of Sciences and Arts. He chaired the Academy from 1950 to 1952. He published the Historical Grammar of Slovenian (Volume 2: Consonantism, 1924; Volume 7: Dialects, 1935), Dialect Map of Slovenian (1931), A Short History of Slovenian (1936), and Slovenian Morphology (1952).

2. The online portal FRAN is named after Fran Ramovš.

3. For more information on the setting of Slovenian lexicography and on the development and influences of Slovenian lexicographic theory, see Vrbinc, Farina and Vrbinc (2018a). 
4. "Lexicography was never a science, it is not a science, and it will probably not become a science. Scientific activities as a whole are aimed at producing theories, and precisely this is not true of lexicographical activities. We must bear in mind that writing on lexicography is part of meta-lexicography and that the theory of lexicography is not part of lexicography" (Wiegand 1984, 13).

5. This two-part reference work consists of a section on the rules of Slovenian orthography and a dictionary section; it might more accurately be called a manual of Slovenian orthography.

\section{References}

\section{Dictionaries}

Bajec, Anton et al. 1970-1991. Slovar slovenskega knjižnega jezika. Ljubljana: Državna založba Slovenije.

Cigale, Matej. 1860. Deutsch-slowenisches Wörterbuch. 2 vols. Laibach: Herausgegeben auf Kosten des Hochwürdigen Herrn Fürstbischofs von Laibach, Anton Alois Wolf.

Debenjak, Doris, Božidar Debenjak and Primož Debenjak. 1992. Veliki nemško-slovenski slovar. Ljubljana: Državna založba Slovenije.

Debenjak, Doris, Božidar Debenjak and Primož Debenjak. 1995. Veliki slovensko-nemški slovar. Ljubljana: Državna založba Slovenije.

Grad, Anton, Ružena Škerlj and Nada Vitorovič. 1973. Angleško-slovenski slovar. Ljubljana: Državna založba Slovenije.

Grad, Anton, Ružena Škerlj and Nada Vitorovič. 1978. Veliki angleško-slovenski slovar. Ljubljana: Državna založba Slovenije.

Gutsman, Ožbalt. 1789. Deutsch-windisches Wörterbuch: mit einer Sammlung der verdeutschten windischen Stammwörter, und einiger vorzüglichern abstammenden Wörter. Klagenfurt: gedruckt und im Verlage bey Ignaz Aloys edlen von Kleinmayer ...

Košutnik, Silvester. 1904. Ročni slovensko-angleški in angleško-slovenski slovar: zlasti namenjen za izseljence v Ameriko. Ljubljana: A. Turk.

Kotnik, Janko. 1945. Slovensko-angleški slovar. Ljubljana: Grad.

Krek, Simon et al. 2005-2006. Veliki angleško-slovenski slovar Oxford. Ljubljana: DZS.

Kubelka, Viktor J. 1904. Slovensko-angleški žepni rečnik. New York.

Megiser, Hieronymus. 1592. Dictionarium quatuor linguarum. A lohanne Fabro.

Megiser, Hieronymus. 1603. Thesaurus polyglottus. Frankfurt.

Pleteršnik, Maks. 1894-1895. Slovensko-nemški slovar. Ljubljana: Katoliška tiskarna.

Škerlj, Ružena. 1944. Angleško-slovenski slovar. Ljubljana: Grad.

Snoj, Jerica, Martin Ahlin, Branka Lazar and Zvonka Praznik. 2016. Sinonimni slovar slovenskega jezika. First edition. Ljubljana: Založba ZRC.

Srebnik, Anita. 2006. Slovensko-nizozemski evropski slovar. (Zbirka Evropski slovarji). Ljubljana: Cankarjeva založba.

Srebnik, Anita. 2007. Nizozemsko slovenski slovar = Nederlands Sloveens woordenboek. (Slovarji DZS). First edition. Ljubljana: DZS.

Toporišič, Jože, Franc Jakopin, Janko Moder, Janez Dular, Stane Suhadolnik, Janez Menart, Breda Pogorelec, Kajetan Gantar, Martin Ahlin and Milena Hajnšek-Holz (Eds.). 2001. Slovenski pravopis. Ljubljana: Založba ZRC.

Vrbinc, Alenka and Marjeta Vrbinc. 2009. Angleško-slovenski slovar. Ljubljana: Cankarjeva založba. 


\section{Other references}

Čibej, Jaka, Vojko Gorjanc, Iztok Kosem and Simon Krek (Eds.). 2018. Proceedings of the XVIII Euralex International Congress: Lexicography in Global Contexts, 17-21 July 2018, Ljubljana. Ljubljana: Ljubljana University Press, Faculty of Arts.

Farina, Donna M.T.Cr. 2020. 20th-century Soviet-Russian Dictionary Front Matter: Focus on the Linguistic Norm. Lexicography 7(1-2): 115-122. Available: https://doi.org/10.1007/s40607-020-00064-z

Fuertes-Olivera, Pedro A. and Sven Tarp. 2014. Theory and Practice of Specialised Online Dictionaries: Lexicography versus Terminography. Berlin/New York: De Gruyter.

Gouws, Rufus H. 2012. Who can Really be Called a Lexicographer? Lexikos 22: 217-225. Available: http://lexikos.journals.ac.za/pub/article/view/1004 and https://doi.org/10.5788/ 22-11004

Gouws, Rufus H. 2018. 'n Leksikografiese datatrekkingstruktuur vir aanlyn woordeboeke [A Lexicographic Data Pulling Structure for Online Dictionaries]. Lexikos 28: 177-195. Available: https://doi.org/10.5788/28-1-1461

Hartmann, Reinhard Rudolf Karl (Ed.). 1984. LEXeter' 83 Proceedings. Papers from the International Conference on Lexicography at Exeter, 9-12 September 1983. Tübingen: Max Niemeyer.

Jackson, Howard (Ed.). 2013. The Bloomsbury Companion to Lexicography. London: Bloomsbury.

Merše, Majda. 2009. Slovensko zgodovinsko slovaropisje s konceptualno-razvojnega vidika. Stabej, Marko (Ed). 2009: 251-255.

Available: https://centerslo.si/wp-content/uploads/2015/10/28-Merse.pdf

Piotrowski, Tadeusz. 2013. A Theory of Lexicography: Is There One? Jackson, Howard (Ed.). 2013: 303-320.

Ramovš, Fran. 1924. Historična gramatika slovenskega jezika: Konzonantizem II. Ljubljana: Učiteljska tiskarna.

Ramovš, Fran. 1931. Dialektološka karta slovenskega jezika. Založila rektorat univerze kralja Aleksandra I. in J. Blasnika nasl., univerzitetna tiskarna v Ljubljani.

Ramovš, Fran. 1935. Historična gramatika slovenskega jezika: Dialekti VII. Ljubljana: Učiteljska tiskarna.

Ramovš, Fran. 1936. Kratka zgodovina slovenskega jezika. Ljubljana: Akademska založba.

Ramovš, Fran. 1952. Morfologija slovenskega jezika. Ljubljana: Državna založba Slovenije za Univerzitetno študijsko komisijo.

Rener, Tanja. 2007. Ružena Škerlj (1904-1992): svetovljanka, razumnica, (so)avtorica številnih izdaj angleško-slovenskega slovarja ter slovensko-češkega in češko-slovenskega slovarja. Šelih, Alenka et al. (Eds.). 2007: 404-406.

Sajous, Franck, Amélie Josselin-Leray and Nabil Hathout. 2018. Lexical and Semantic Neology in English: The Complementarity of Crowdsourced Dictionaries and Professional Dictionaries Viewed through the Filter of Neology. Lexis. Journal in English Lexicology 12: 1-34.

Šelih, Alenka, Milica Antić Gaber, Alenka Puhar, Tanja Rener, Rapa Šuklje and Marta Verginella (Eds.). 2007. Pozabljena polovica: Portreti žensk 19. in 20. stoletja na Slovenskem. Ljubljana: Založba Tuma and SAZU.

Stabej, Marko (Ed). 2009. Infrastruktura slovenščine in slovenistike. Obdobja, Symposium 28. Ljubljana: Znanstvena založba Filozofske fakultete. 
Tarp, Sven. 2012. Do We Need a (New) Theory of Lexicography? Lexikos 22: 321-332. Available: https://doi.org/10.5788/22-1-1010

Vrbinc, Alenka, Donna M.T.Cr. Farina and Marjeta Vrbinc. 2018a. Objectivity, Prescription, Harmlessness, and Drudgery: Reflections of Lexicographers in Slovenia. Lexikos 28: 361-383. Available: https://doi.org/10.5788/28-1-1469

Vrbinc, Alenka, Donna M.T.Cr. Farina and Marjeta Vrbinc. 2018b. Slovenian Lexicographers at Work. Čibej, Jaka, Vojko Gorjanc, Iztok Kosem and Simon Krek (Eds.). 2018: 199-208.

Wiegand, Herbert Ernst. 1984. On the Structure and Contents of a General Theory of Lexicography. Hartmann, Reinhard Rudolf Karl (Ed.). 1984: 13-30.

Wolfer, Sascha and Carolin Müller-Spitzer. 2016. How Many People Constitute a Crowd and What Do They Do? Quantitative Analyses of Revisions in the English and German Wiktionary Editions. Lexikos 26: 347-371.

Available: http://dx.doi.org/10.5788/26-1-1346 